\title{
A GAZDASÁGI TANÁCSOKKAL KAPCSOLATOS MÜKÖDÉSI TAPASZTALATOK AZ EGYETEMEKEN
}

\author{
Keczer Gabriella \\ adjunktus, Szegedi Tudományegyetem Mérnöki Kar
}

Summary

The higher education reform launched in 2002 intended to introduce university governance in Hungarian universities, but because of the protest of the academic sector, and of constitutional discrepancies the initiative failed. The only result was setting up economic councils as consultative bodies in the management of the universities, with very narrow scope of power. On the basis of interviews conducted with 10 university leaders representing 8 leading Hungarian universities we can state that the economic councils do not function well and they cannot be turned into governing bodies.

\section{Ǒsszefoglaló}

A 2002-ben elindított felsőoktatási reform az egyetemi kormányzás rendszerének bevezetését tüzte ki célul a tradicionális egyetemirányítás felváltására, de részben az akadémiai szféra ellenállása, részben alkotmányossági problémák miatt a kezdeményezés kudarcba fulladt. Egyetlen eredménye az irányítás területén az úgynevezett gazdasági tanács intézményének létrehozása volt, igen szük, tanácsadói hatáskörrel. Egy 10 egyetemvezetővel, 8 felsőoktatási intézményben lefolytatott mélyinterjú-sorozatból kiderül, hogy az intézmények felében a gazdasági tanácsok nem mükődnek megfelelően, és az egyetemvezetők többsége szerint nem alkalmasak arra, hogy az egyetemi kormányzás rendszerének megfelelően, nagyobb hatalommal bíró irányító testületekké alakuljanak.

\section{Elözmények}

A rendszerváltás utáni törvényi szabályozás, az 1993-as felsöoktatási törvény (FTV) a magyar egyetemeken a hagyományos, kontinentális európai gyökerü, kollektív döntéshozatalon, a tradicionális egyetemi testületek (intézményi tanácsok) hatalmán alapuló, professzionalitást nélkülöző irányítási rendszert hozott létre. Az átalakítás szükségességét egy hatékonyabb irányítást és mủködést biztosító rendszerré szinte az 1993-as törvény megszületése óta hangsúlyozták a szakemberek.

A magyar egyetemirányítás reformját az oktatási kormányzat 2002-ben kezdeményezte. Elindították a Csatlakozás az Európai Felsőoktatási Térséghez (CSEFT) elnevezésü programot, melynek célja egyebek között az egyetemirányítás modernizációja volt. A CSEFT koncepcióját kidolgozó szakemberek az egyetemi kormányzás bevezetését szorgalmazták, amely angolszász győkerü, a hagyományosnál professzionálisabb irányításba bevonja az érdekháló külsỏ tagjait is az irányító testületen (board) keresztül.

Az elképzelések szerint a hazai egyetemeken a hatalmon három szereplő osztozott volna:

- az irányító testület (IT), amely stratégiai és gazdálkodási kérdésekben döntene és tagjait fele részben a fenntartó, fele részben az intézmény delegálná;

- a szenátus, melynek hatáskőre akadémiai kérdésekre korlátozódna;

- és az IT által megválasztott rektor, aki a végrehajtói jogköröket gyakorolná. 
Az új FTV-tervezetet a CSEFT koncepció alapján dolgozták ki. Az oktatási kormányzat ezt nyilvános vitára bocsátotta, melynek következményeként, a felsõoktatási szféra jelentõs ellenállásának hatására az előterjesztés számos változatot megélt, jelentỏsen felpuhult, benyưjtása elhúzódott, és végull csak 2005 tavaszán kerâl az országgyúlés elé. A legnagyobb ellenállás éppen az egyetemek irányításának átalakításával kapcsolatosan bontakozott ki.

Sajátos módon végul még ez a jelentősen felpuhult törvény sem állta $\mathrm{ki}$ az alkotmányosság próbáját. A kőztársasági elnők a tōrvény elfogadása után normakontrollra küldte azt az Alkotmánybíróságnak (AB), mert véleménye szerint a jogszabály az IT hatáskörébe utal a kutatást kőzvetlenull érintō kérdéseket, megsértve ezzel a tudományos élet szabadságának alkotmányos elvét [KEH 2005]. 2005 októberében az AB megállapította, hogy a törvény által elöírt egyetemirányítási rendszerben valóban sérul a tanszabadság, a tudományos élet szabadsága és a felsőoktatási intézmények autonómiája [AB 2005].

Az oktatási kormányzat így a jogszabály teljes átdolgozására kényszerült: a 2005. november 29-én elfogadott „2005. évi CXXXIX. Törvény a felsőoktatásról” nem változtatta meg az egyetemek belső irányítását. Mindőssze egy többségében belső tagokból álló, tanácsadó jellegũ testületet, úgynevezett gazdasági tanácsot (GT) hozott létre.

2006-ban a kormányzat kísérletet tett a törvény módosítására a GT szerepének erősítése érdekében. A 2006. július 24-i törvénymódositás értelmében a rektor csak a GT egyetértésével nyújthatott volna be a szenátusnak bizonyos elōterjesztéseket, igy például az intézményi fejlesztési tervet, az egyetem számviteli rendjét, fejlesztésre vonatkozó elképzeléseket, gazdálkodó szervezet alapítására vonatkozó kezdeményezést, a vagyongazdálkodással kapcsolatos terveket, az intézmény kỏltségvetését és beszámolóját. A köztársasági elnök elődjêhez hasonlóan normakontrollra kủldte a törvénymódosítást [KEH 2006], az AB pedig szeptember 25-én helyt adott az elnök alkotmányossági aggályainak. Az indoklás szerint a GT nem felsőoktatási önkormányzati szerv, mégis lehetővé válna számára az egyetem autonóm döntéshozatalának megakadályozása, az egyetértési jog gyakorlása során pedig meggátolhatja a tudományos minőség érvényesulését. [AB 2006]

\section{A gazdasági tanácsok szerepe az egyetemirányításban}

A jelenleg hatályos „2005. évi CXXXIX. törvény a felsőoktatásról” 3 fő aktort nevez meg az egyetemek irányításában, különbözỏ szerepekben:

- a felsőoktatási intézmény vezetỏje a rektor;

- dőntést hozó és a döntés végrehajtását ellenőrző testülete a szenátus;

- véleményező, a stratégiai döntések elökészitésében részt vevő és a döntések végrehajtásának ellenőrzésében közremúködő szerve a gazdasági tanács. /20.§/

A korábbi két szereplö (rektor és egyetemi tanács) mellé tehát harmadik aktorként belép a GT. A döntési és ellenőrzési hatáskőr azonban továbbra is a korábbi ET-ből szenátussá alakult testületé maradt. A GT-nek a törvény szerint az egyetem müködésével kapcsolatban általános tanácsadói-javaslattevői-közremüködői szerepe van $/ 23 . \S(1) /$, melyet véleményezés formájában gyakorol gazdálkodási, fejlesztési kérdésekben $/ 25 . \S$ (1)/. Konkrét döntési jogosultságot egyedül a felsỏoktatási intézmény kezelésében lévó kincstári vagyon elidegenítésével, megterhelésével kapcsolatban kapott $/ 23 . \S$ (1)/, konkrét ellenơrzési szerepet pedig az egyetem gazdálkodásával kapcsolatban $/ 25 . \S(2) /$. A GT szerepe jelenleg tehát elsõsorban az állami vagyon és a közpénzek védelme. 
A. GT összetételét pontosan szabályozza a törvény:

- a tagok száma 15 ezres hallgatói létszám alatt 7, a fölött 9 fö;

- ebböl 3-4 föt a szenátus (köztük 1 föt a hallgatók), 2-3 főt a miniszter delegál;

- hivatalból tag a rektor és a gazdasági föigazgató $/ 23 . \S(4,5)$.

A GT-ben tehát erős egyetemi túlsúly van: 7-böl 5 illetve 9-böl 7 fö. Az összeférhetetlenségeket, elsősorban a politikához, a kormányzathoz és más felsőoktatási intézményekhez kapcsolódó személyek kizárásával részletesen szabályozza a törvény. $123 . \S$ (7) $/$.

\section{A gazdasági tanácsok múködésének eddigi tapasztalatai}

A gazdasági tanácsok müködésével kapcsolatos eddigi tapasztalatok feltárására mélyinterjúsorozatot készítettem 10 hazai felsöoktatási vezetővel (rektor, rektorhelyettes, dékán), akik 8 felsőoktatási intézményt képviselnek.

A mélyinterjú sorozatból egyértelmủen kiderül, hogy a GT-k eddigi müködését meglehetősen eltérően értékelik az egyes vezetők. 4 megkérdezettnek egyértelmüen kedvezőek a tapasztalatai; a GT-ket hasznosnak, müködésüket eredményesnek tartják. 4 vezető szerint viszont értelmetlen a létük, nem müködnek megfelelöen. 2 válaszadó szerint maga a GT jól, de hatalom híján hatástalanul müködik. Érdekes módon egyazon intézményen belül is eltérően értékelik a GT-k müködését a különböző szintü vezetők. Általánosságban azonban elmondható, hogy a rektori vezetés általában hasznosnak tartja a GT-t, a dékánok viszont haszontalannak.

Azok a vezetők, akiknek kedvező tapasztalataik vannak a GT-kkel kapcsolatban, a következőket emelték ki: jó ötleteik vannak, külső kontrollt biztosítanak, felelösen gondolkodnak az egyetemröl, elfogulatlan, külsö véleményt képviselnek, racionális megközelítést alkalmaznak. Éppen ennek ellenkezöjét érzékelik azok, akik egyértelmüen a GT-k ellen foglalnak állást: a tagok felkészületlenek, képzetlenek, elkötelezetlenek, ad-hoc módon alakítják ki véleményüket, politikai szempontok befolyásolják öket, a tagok túlságosan elfoglaltak és nincs idejük erre a tevékenységre, nem ismerik és nem értik az egyetem múködését. Az egyik rektor úgy fogalmazott, hogy a GT külső tagjai a miniszter szakmai-személyes ismeretségi köréből kerültek ki, és a föhatóság revizoraként müködnek az egyetemen.

Azok, akik szerint a GT-k jól múködnek, de hatalom híján nincs befolyásuk a döntésekre. Úgy vélik, bizonyos kérdésekben a GT helyes döntést hozott, a szenátus viszont nem fogadta el. Ilyen volt például az egyik egyetemen a rektorválasztás: a GT egy objektív pontrendszer alapján választotta ki a legjobb jelöltet, de a szenátus mást választott meg rektornak. Ezek a vezetök attól is tartanak, hogy ha a GT-kben ülö komoly szakemberek hosszabb időn át azt tapasztalják, hogy nincs befolyásuk az egyetemen a dolgok menetére, „se pénz, se dicsőség” helyzetben nem fogják tovább vállalni a megbízást, és a GT-k „kiürülnek”.

Azt, hogy a GT-k a jelenleginél nagyobb hatáskört kapjanak és akár az egyetemi kormányzás rendszerének részeként irányitó testületté alakuljanak természetesen azok a megkérdezettek is támogatják, akiknek egyértelmüen jó tapasztalataik vannak eddigi müködésükkel kapcsolatban. A rektor megválasztását, a költségvetés elkészítését, a szervezeti átalakításokról szóló döntéseket utalnák a GT-k hatáskörébe. Azok viszont, akiknek kedvezőtlenek az eddigi tapasztalataik, egyenesen tragikusnak, veszélyesnek tartanák, ha a GT-k nagyobb hatáskört kapnának. Szerintük, ha valódi hatalommal rendelkező irányító 
testületeket kívánna a minisztérium létrehozni, teljesen más alapokra kellene helyezni a tagok kiválasztását. Sokkal szélesebb körböl, nyiltan, országos, esetleg nemzetközi pályázaton, objektiv kritériumok alapján kellene a tagokat kiválasztani és szigorú összeférhetetlenségi szabályokat kellene kialakítani annak érdekében, hogy a külső tagok ne a politika és ne egy másik intézmény érdekeit, szempontjait képviseljék.

Az egyik vezető szerint viszont mindenképpen az egyetemmel valamilyen kapcsolatban álló, külsö személyeket kellene felkérni erre a feladatra. Ennél a kérdésnél viszont ismételten megjelentek a kormányzási rendszer magyarországi müködőképességével kapcsolatos kételyek: van-e Magyarországon kellö számú, megfelelő személy az egyetemek irányító testulleteinek feltöltésére.

\section{Következtetések, javaslatok}

A külső kontroll megjelenése az egyetemek müködésében a kormányzási rendszertől függetlenül is szükséges. A gazdasági tanácsokkal kapcsolatos kételyek jellegéböl (szük merítési bázis, személyi-politikai összefonódások veszélye, szakértelem és elkötelezettség hiánya stb.) következik, hogy nem személy-orientált, inkább testületi és technokratikus megoldásokban lenne célszerü gondolkodni. Részben vagy egészben egyetemeken kivüli tagokból (oktatási kormányzat, gazdasági szféra, társadalmi szervezetek) létrejöhetne egy olyan (leginkább az amerikai állami szintü boardokhoz hasonló) országos testület, minden egyetem esetében egyedileg kiegészülve a helyi közösség képviselöivel, amely előzetesen véleményezi az egyetemek intézményfejlesztési terveit, utólag pedig értékeli a teljesítményszerzödésekben foglaltak teljesullését. Jelentéseit nyilvánosságra hozva hozzájárulhatna a valódi verseny kialakulásához a felsỏoktatási intézmények között, és alapját képezhetné a hallgatói létszámkeretek és az erőforrások teljesítményalapú elosztásának is. A testület tagjait azonban rendkívül körültẹintöen kell kiválasztani, és megfelelö felkészítö, beillesztö programokkal a feladatra alkalmassá kell tenni. Ebből a testületböl alakulhatnának mẹg később az egyes intézmények irányító testületei.

\section{Felhasznált irodalom:}

AB - Alkotmánybíróság (2005): 41/2005. (X. 27) sz határozat.

AB - Alkotmánybíróság (2006): 39/2006. (IX. 27) sz határozat.

KEH - Köztársasági Elnöki Hivatal (2005): I-2/2122/2005 sz. dokumentum.

KEH - Köztársasági Elnöki Hivatal (2006): I-2/3388/2006 sz. dokumentum.

2005. évi CXXXIX. Törvény a felsőoktatásról. 